\title{
Batch and Fixed-Bed Column Studies on Palladium Recovery from Acidic Solution by Modified $\mathrm{MgSiO}_{3}$
}

\author{
Cosmin Vancea ${ }^{1}$, Maria Mihailescu ${ }^{1,2}$, Adina Negrea ${ }^{1} \mathbb{D}$, Giannin Mosoarca ${ }^{1, *(\mathbb{D})}$ \\ Mihaela Ciopec ${ }^{1, *}$, Narcis Duteanu ${ }^{1}{ }^{1}$, Petru Negrea ${ }^{1}$ and Vasile Minzatu ${ }^{2}$ \\ 1 Faculty of Industrial Chemistry and Environmental Engineering, Politehnica University Timisoara, \\ 300223 Timisoara, Romania; cosmin.vancea@upt.ro (C.V.); mihailescumia@gmail.com (M.M.); \\ adina.negrea@upt.ro (A.N.); narcis.duteanu@upt.ro (N.D.); petru.negrea@upt.ro (P.N.) \\ 2 Research Institute for Renewable Energy, Politehnica University Timisoara, 138 Musicescu Street, \\ 300774 Timisoara, Romania; vasile.minzatu@student.upt.ro \\ * Correspondence: giannin.mosoarca@upt.ro (G.M.); mihaela.ciopec@upt.ro (M.C.); \\ Tel.: +40-256404185 (G.M.); +40-256404192 (M.C.)
}

Received: 18 November 2020; Accepted: 16 December 2020; Published: 18 December 2020

\begin{abstract}
Effective recovery of palladium ions from acidic waste solutions is important due to palladium's intensive usage as a catalyst for different industrial processes and to the high price paid for its production from natural resources. In this paper, we test the ability of a new adsorbent, $\mathrm{MgSiO}_{3}$ functionalized by impregnation with DL-cysteine (cys), for palladium ion recovery from waste solutions. The Brunauer-Emmett-Teller (BET) surface area analysis, Barrett-Joyner-Halenda (BJH) pore size and volume analysis, scanning electron microscopy (SEM), energy dispersive X-ray (EDX) spectroscopy and Fourier-Transformed Infrared (FTIR) spectroscopy have been performed to characterize this material. Firstly, the maximum adsorption capacity of the new obtained material, $\mathrm{MgSiO}_{3}$-cys, in batch, was studied. To establish the adsorption mechanism, the obtained experimental data were fitted using the Langmuir, Freundlich and Sips adsorption isotherms. Studies on the adsorption of palladium ions on the synthesized material were performed in a dynamic regime, in a fixed-bed column. The Pd(II) recovery mechanism in the dynamic column regime was established based on Bohart-Adams, Yoon-Nelson, Thomas, and Clark models. The obtained equilibrium adsorption capacity was $9.3\left(\mathrm{mg} \mathrm{g}^{-1}\right)$ in static regime (batch) and $3\left(\mathrm{mg} \mathrm{g}^{-1}\right)$ in dynamic regime (column). The models that best describe the Pd(II) recovery process for batch and column adsorption are Sips and Clark, respectively.
\end{abstract}

Keywords: palladium recovery; $\mathrm{MgSiO}_{3} ; \mathrm{DL}$-cysteine; batch adsorption; fixed-bed column adsorption

\section{Introduction}

The noble metals platinum, palladium and rhodium have a wide application range based on their distinct physical and chemical properties [1-5]. One of the first historical uses of the precious metals was as currency, internationally recognized under ISO 4217. Palladium and its alloys are currently used by the telecommunication and automotive industries (as catalytic converters), the metallurgy and chemical industries, for jewelry manufacturing and in the medical field (dental alloy production) [5-9].

Its growing popularity led, in 2010, to official recognition as the fourth most precious metal, after gold, silver and platinum, a statute that requires the marking of each jewel. White gold contains variable amounts of palladium (up to $20 \%$ ); furthermore, dental alloys can contain up to $10 \%$ palladium [5,10-15]. 
Due to its increased used, palladium has become an important contact allergen, with palladiumpositive patch-tests being reported by different countries-from $2 \%$ in Northern Ireland to $13 \%$ in Israel. The main aspects of palladium allergy are contact dermatitis, rash for lichen planes, stomatitis, and mouth burns [16].

Because natural platinum resources are limited, the recovery of platinum-group metals is a challenge of great importance. The two main classes of recyclable precious metal wastes are (i) precious metals including tableware, jewelry, coins, electronic waste, and spent catalysts, and (ii) secondary products of recovery/processing/use of precious metals and, namely, waste: sludge, anodic sludge, ash, filters, refractory materials, crucibles, photographic films, and resins [5].

Palladium compounds are toxic and carcinogenic for humans. Palladium is easily accumulated into plants, transported through their roots, and, finally, along the food chain [17]. Excessive exposure to palladium has adverse effects on human health, such as skin and eye irritation, substantial DNA and cell mitochondrial degradation, and deterioration and inhibition of hydroxyl radicals associated with enzymatic activity [18]. As environmental issues related to palladium contamination continue to grow, finding advantageous extracting alternatives becomes very important. Some of the analytical techniques used for palladium ion recovery by separation and preconcentration are coprecipitation, solvent extraction, electro-deposition, or membrane filtration [19-25].

These techniques have some major disadvantages such as lack of sensitivity and selectivity, high cost, and high consumption of toxic organic solvents [26-29]. Recently, a new separation technique has emerged, having many advantages over traditional extraction methods: high enrichment factor, better separation, selectivity and high efficiency, ease of recovery and reuse, low cost due to the low consumption of organic reagents and solvents, and, most importantly, environmentally friendly. This method consists of using a preconcentration of the metal ion of new materials obtained by functionalization of chemically inert supports with various pendant groups. Some of the advantages of these new materials are high chemical and thermal stability, fast availability, economic viability, and easy and robust surface immobilization. The materials most commonly used as supports are commercial polymeric resins [30-32], resins such as Dowex 1-X10 [33], Bio-Rad AG1-8x [34], Dowex 1-X8 and Amberlite IRN -78 [35-39], Amberlite IRA-958, Lewatit MP-500 A, and Purolliet A-850 [40,41], natural polymers [42], inorganic silicone compounds [43], magnesium silicate [44,45], and ionic liquids crown ethers [46].

Selection of the sorbent material is a complex decision, the choice being influenced by the palladium form in the considered waste and many other factors. The absorbent materials technology can be efficient at the laboratory scale, but could be a failure at industrial level. Thus, the choice of sorbent material in close correlation with treatment technology for liquid acid waste is very important.

Adsorption is an advanced method, efficient and with high potential for metal ion removal from aqueous solutions. Therefore, it is important to develop new materials having advanced sorbent properties. Materials can be improved by functionalization of the solid support with an extractant containing certain groups designed to improve the sorbent properties of the support. Organic compounds with structural N, P, or S pendant groups can be used as extractors for functionalization of the support [44,47].

Therefore, new chemical modification methods of the inorganic or organic supports have been developed by functionalization with different extractants.

Common techniques at present include the wet method, the dry method, the adding modifiers method, and the dynamic column method, which has the following advantages: a short functionalization time and an increased effectiveness of the adsorption process [48-53].

In order to apply these methods, some restrictions must be considered-the extractant must be liquid or be kept in a liquid state by the addition of solvent; the extractant and solvent must have a minimum solubility; the support must be prepared for impregnation; and the functionalization method must not alter the properties of the extractant or support [51]. 
The purpose of this study was to develop an ecological strategy for $\mathrm{Pd}(\mathrm{II})$ recovery using (florisil) $\mathrm{MgSiO}_{3}$ functionalized by impregnation with DL-cysteine (cys) [49]. This new material has -SH, $-\mathrm{NH}_{2}$, and $-\mathrm{COOH}$ pendant groups derived from the amino acid DL-cysteine [54,55].

The first objective was to test the new $\mathrm{MgSiO}_{3}$ cys material's ability to recover palladium ions from waste solutions by adsorption. The second goal of this research was to compare the static adsorption process with the dynamic one.

\section{Materials and Methods}

\subsection{Adsorbent Synthesis and Characterization}

Functionalized $\mathrm{MgSiO}_{3}$ using DL-cysteine (DL-cysteine-hydrochloride monohydrate 99.0\%, Fluka, Buchs, Switzerland) as extractant was obtained using $0.1 \mathrm{~g}$ of DL-cysteine. This amount of extractant was dissolved in $25 \mathrm{~mL}$ of deionized water. The obtained solution was mixed with $1 \mathrm{~g}$ of support $\left(\mathrm{MgSiO}_{3}\right.$, 60-100 mesh, Merck, Darmstadt, Germany), corresponding to a ratio support: extractant of 1:0.1 and they were brought into contact for $24 \mathrm{~h}$ in stand-by (SIR, solvent impregnated resin-dry method) [49,51]. After that, the obtained material was dried in the oven (Pol-Eko SLW 53 STD, POL-EKO-APARATURA, Wodzisław Ślaski, Poland) for $24 \mathrm{~h}$ at $323 \mathrm{~K}$. The appearance of the adsorbent material can be seen in Figure 1.

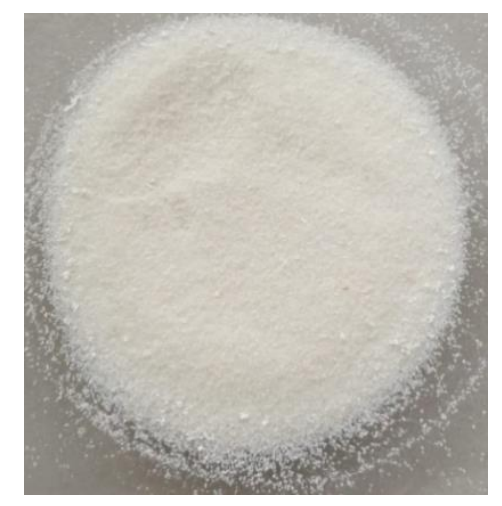

Figure 1. The appearance of the adsorbent material obtained by functionalizing $\mathrm{MgSiO}_{3}$ using DL-cysteine.

The specific surface area, cumulative pore volume, and pore size of the adsorbent material were measured with a Micromeritics ASAP 2020 instrument (Brunauer-Emmett-Teller, BET, surface area analysis and Barrett-Joyner-Halenda, $\mathrm{BJH}$, pore size and volume analysis, at liquid nitrogen temperature, $-196{ }^{\circ} \mathrm{C}$ ) from Micromeritics Instrument, Norcross, GA, USA. The point of zero charge $\left(\mathrm{pH}_{\mathrm{PZC}}\right)$ and density were determined using the solid addition method and pycnometer method, respectively. Furthermore, the adsorbent was analyzed by scanning electron microscopy (SEM) and energy dispersive X-ray (EDX) spectroscopy, using the FEI Quanta FEG 250 instrument (FEI, Eindhoven, The Netherlands), and Fourier-Transformed Infrared (FTIR) spectroscopy using a Bruker Platinum ATR-QL Diamond apparatus (Bruker Optik GmbH, Ettlingen, Germany) in the range of $4000-400 \mathrm{~cm}^{-1}$.

\subsection{Batch Adsorption Experiments}

The effect of the initial concentration of Pd(II) upon the adsorption capacity of the materials was studied using Pd(II) solutions of different concentrations (5, 10, 20, 30, 40, and $50 \mathrm{mg} \mathrm{L}^{-1}$ ), prepared by the appropriate dilution of a stock solution of palladium (II) chloride ( $5 \mathrm{wt} \%$ in $10 \mathrm{wt} \% \mathrm{HCl}$, Sigma-Aldrich, St. Louis, MO, USA). Adsorptions were carried out at $\mathrm{pH}=2$ for one hour at $298 \mathrm{~K}$. The equilibrium concentration was determined using thermostatic Julabo SW23 water bath and shaken at a rotation speed of $200 \mathrm{rpm}$. The adsorption mechanism was established by modeling the experiment 
using three specific isotherms in non-linear form: Langmuir, Freundlich and Sips, according to equations used in scientific literature [56-59].

$$
\begin{aligned}
& \text { Langmuir } q_{e}=\frac{q_{m} \cdot K_{L} \cdot C_{e}}{1+K_{L} \cdot C_{e}} \\
& \text { Freundlich } q_{e}=K_{F} \cdot C_{e}^{1 / n_{F}} \\
& \text { Sips } q_{e}=\frac{q_{m} \cdot K_{S} \cdot C_{e}^{1 / n_{S}}}{1+K_{S} \cdot C_{e}^{1 / n_{S}}}
\end{aligned}
$$

where $q_{e}$ is the maximum absorption capacity $\left(\mathrm{mg} \mathrm{g}^{-1}\right), q_{m}$ is maximum adsorption capacity $\left(\mathrm{mg} \mathrm{g}^{-1}\right)$, $K_{L}$ is the Langmuir constant, $C_{e}$ is the equilibrium concentration of $\mathrm{Pd}(\mathrm{II})$ in solution ( $\left.\mathrm{mg} \mathrm{L}^{-1}\right), K_{F}$ is the Freundlich constant, $1 / n_{F}$ is the heterogeneity factor, $K_{S}$ is Sips constant, and $1 / n_{S}$ is the Sips model exponent.

Three independent replicates were performed for each batch adsorption experiment.

\subsection{Column Adsorption Experiments}

The obtained sorbent, $\mathrm{MgSiO}_{3}$ functionalized using DL-cysteine $\left(\mathrm{MgSiO}_{3}-\right.$ cys), was used for dynamic studies in a fixed-bed column. Pd(II) solutions' initial concentration was $60\left(\mathrm{mg} \mathrm{L}^{-1}\right)$, prepared using appropriate dilution of a stock solution of palladium (II) chloride ( $5 \mathrm{wt} \%$ in $10 \mathrm{wt} \%$ $\mathrm{HCl}$, Sigma-Aldrich, St. Louis, MO, USA).

The experimental setup was made using a glass column (diameter $20 \mathrm{~mm}$ and height $300 \mathrm{~mm}$ ) loaded with three different amounts of adsorbent material (10,5, and $3 \mathrm{~g})$, corresponding to three layers' heights (70, 35, and $21 \mathrm{~mm}$, respectively) (Figure 2). The $\mathrm{Pd}(\mathrm{II})$ solution was transferred in the experimental column using a peristaltic pump (Heidolph SP quick, Heidolph Instruments, Schwabach, Germany) at a flow rate of $7\left(\mathrm{~mL} \mathrm{~min}^{-1}\right)$. The studies were made using samples sequences of $25 \mathrm{~mL}$. The retention times of the solution in the adsorption column, corresponding to the amounts of adsorbent mentioned above, were approximately 3, 1.5, and $1 \mathrm{~min}$, respectively. The residual concentration of $\mathrm{Pd}(\mathrm{II})$ was measured using an atomic absorption spectrometer type Varian AAS 280 FS (Varian Inc., Mulgrave, Australia).

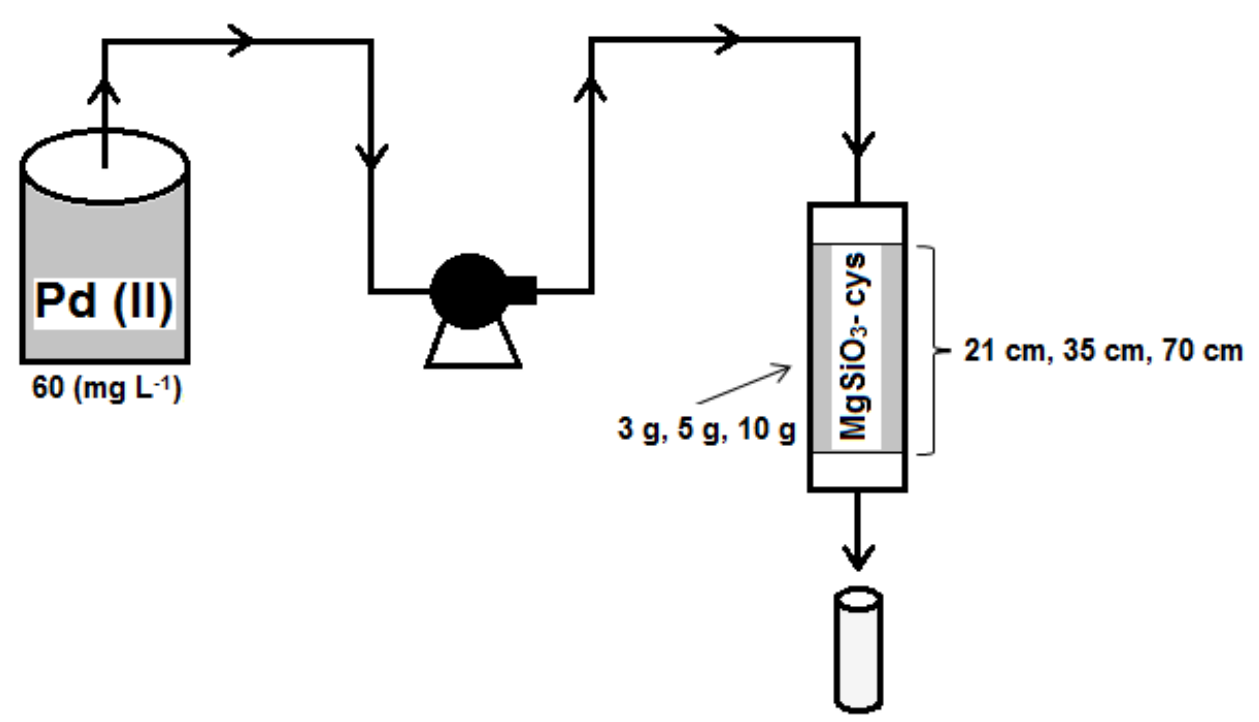

Figure 2. The scheme of the experimental Pd(II) removal installation in a fixed-bed adsorption column.

For each adsorption column experiment, there were three independent replicates. 
The column adsorption mechanism was established using four specific models: Bohart-Adams, Thomas, Yoon-Nelson, and Clark (linear form), according to equations described elsewhere [60-65].

$$
\begin{gathered}
\text { Bohart-Adams } \ln \left(\frac{C_{t}}{C_{0}}\right)=k_{B A} \cdot C_{0} \cdot t-k_{B A} \cdot N_{0} \cdot \frac{Z}{F} \\
\text { Thomas } \ln \left(\frac{C_{0}}{C_{t}}-1\right)=\frac{k_{T h} \cdot q_{T h} \cdot m}{Q}-k_{T h} \cdot C_{0} \cdot t \\
\text { Yoon-Nelson } \ln \left(\frac{C_{t}}{C_{0}-C_{t}}\right)=k_{Y N} \cdot t-\tau \cdot k_{Y N} \\
\text { Clark } \ln \left(\left(\frac{C_{t}}{C_{0}-C_{t}}\right)^{n-1}\right)=\ln A-r \cdot t
\end{gathered}
$$

where $C_{0}$ is the influent concentration $\left(\mathrm{mg} \mathrm{L}^{-1}\right) ; C_{t}$ is the solution concentration at time $t$ in the effluent $\left.(\mathrm{mg} \mathrm{L})^{-1}\right) ; t$ is time $(\mathrm{min}) ; k_{B A}$ is the kinetic constant of the Bohart-Adam model $\left(\mathrm{L} \mathrm{mg}^{-1} \mathrm{~min}^{-1}\right)$; $F$ is the linear velocity calculated by dividing the flow rate by the column section area; $Z$ is the bed depth of column (cm); $N_{0}$ is the saturation concentration $\left(\mathrm{mg} \mathrm{L}^{-1}\right) ; k_{T h}$ is the Thomas rate constant $\left(\mathrm{L} \mathrm{mi}^{-1} \mathrm{mg}^{-1}\right) ; q_{T h}$ is the equilibrium compound uptake per $\mathrm{g}$ of the resin $\left(\mathrm{mg} \mathrm{g}^{-1}\right) ; m$ is the mass of sorbent resin $(\mathrm{g}) ; Q$ is the flow rate $\left(\mathrm{mL} \min ^{-1}\right) ; k_{Y N}$ is the rate constant $\left(\mathrm{min}^{-1}\right) ; \tau$ is the time required for $50 \%$ adsorbate breakthrough ( $\mathrm{min}) ; n$ is the Freundlich constant determined experimentally in batch; $r$ is the Clark model constant $\left(\mathrm{min}^{-1}\right)$; and $A$ is the Clark model constant.

\section{Results and Discussion}

\subsection{Characterization of the $\mathrm{MgSiO}_{3}-\mathrm{Cys}$}

BET analysis showed that the specific surface area was $S_{\mathrm{BET}}=166\left(\mathrm{~m}^{2} \mathrm{~g}^{-1}\right)$. The average pore size and cumulative pore volume calculated using BJH method were $25.24 \mathrm{~nm}$ and $0.43\left(\mathrm{~cm}^{3} \mathrm{~g}^{-1}\right)$, respectively. The value of $\mathrm{pH}_{\mathrm{PZC}}$ was six and the density was about $4\left(\mathrm{~g} \mathrm{~cm}^{-3}\right)$.

Figure 3 shows the main morphological changes of the surface of the adsorbent material that appeared after impregnation. The presence of functional groups in $\mathrm{MgSiO}_{3}$-cys was investigated using energy dispersive X-ray spectroscopy (EDX) (Figure 4). The EDX spectra of $\mathrm{MgSiO}_{3}$-cys show both magnesium silicate peaks $(\mathrm{O}, \mathrm{Mg}, \mathrm{Si})$ and $\mathrm{N}, \mathrm{S}$, and $\mathrm{C}$ characteristic peaks, confirming the presence of specific peaks for functionalized sorbent.

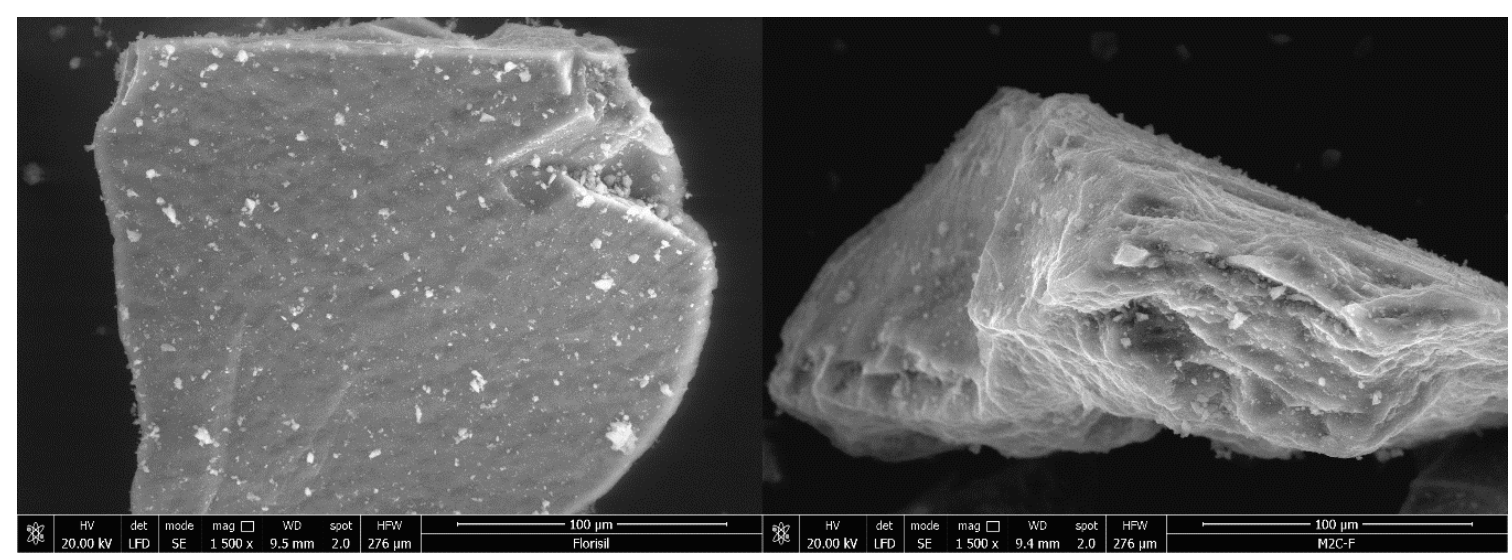

Figure 3. SEM image of adsorbent before and after impregnation. 

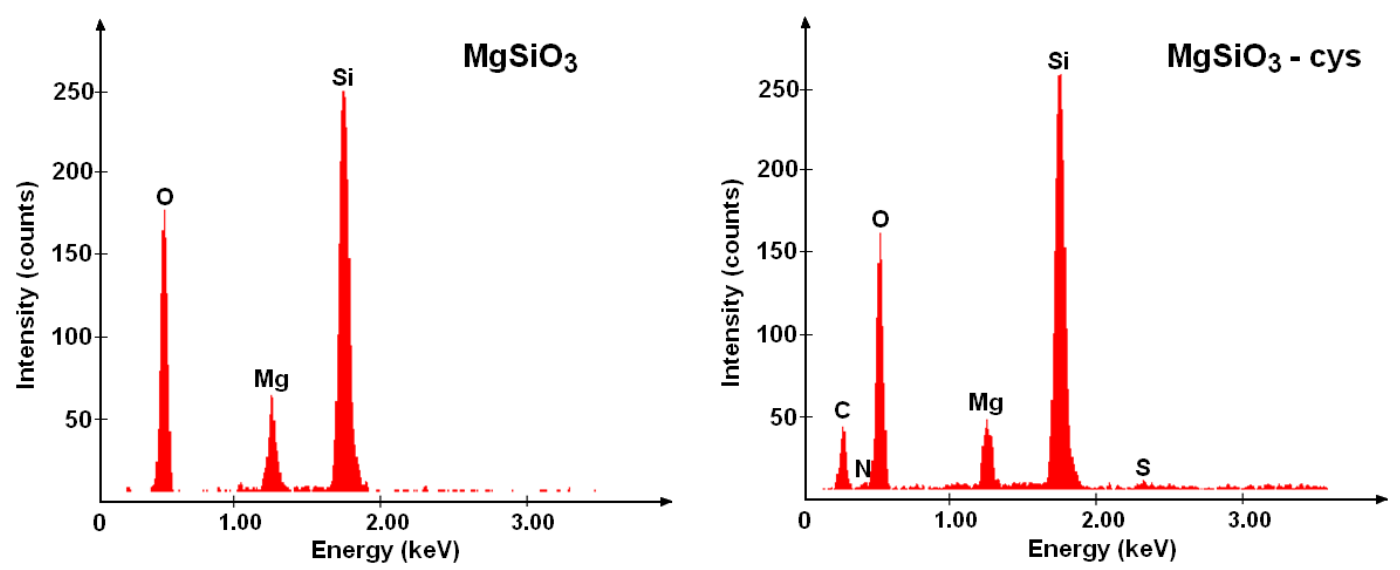

Figure 4. Energy dispersive $\mathrm{X}$-ray (EDX) spectra for $\mathrm{MgSiO}_{3}$ and $\mathrm{MgSiO}_{3}$-cys materials.

Infrared spectroscopy (FTIR) was used to confirm the $\mathrm{MgSiO}_{3}$ functionalization. The FTIR spectra for commercial magnesium silicate together with functionalized $\mathrm{MgSiO}_{3}$-cys are presented in Figure 5. Magnesium silicate-specific peaks can be observed on both spectra: a large peak at $1052 \mathrm{~cm}^{-1}$ and another peak at $600 \mathrm{~cm}^{-1}$, corresponding to Si-O stretching vibrations, and the peak at $800 \mathrm{~cm}^{-1}$, assigned to $\mathrm{Si}-\mathrm{O}-\mathrm{Si}$ bending vibrations. The $\mathrm{MgSiO}_{3}$ spectrum show a band at $\sim 3500 \mathrm{~cm}^{-1}$ and a peak at $1637 \mathrm{~cm}^{-1}$, specific to the $-\mathrm{OH}$ bond from $\mathrm{H}_{2} \mathrm{O}$ molecules.

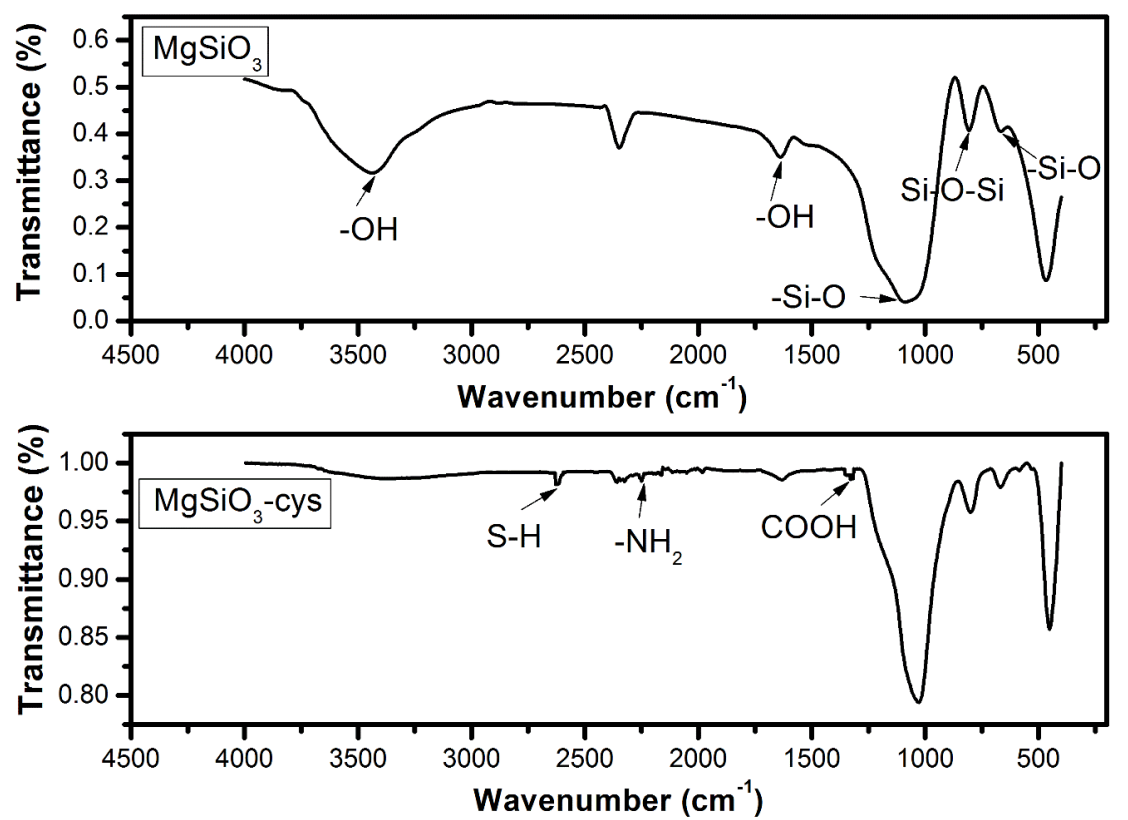

Figure 5. The FTIR spectra for commercial magnesium silicate and functionalized $\mathrm{MgSiO}_{3}$-cys.

The FTIR spectrum of magnesium silicate functionalized with DL-cysteine shows specific peaks for the $-\mathrm{SH}$ bond at $\sim 2620 \mathrm{~cm}^{-1}$, the $-\mathrm{NH}_{2}$ bond at $\sim 2245 \mathrm{~cm}^{-1}$, the $-\mathrm{COOH}$ bond at $\sim 1325 \mathrm{~cm}^{-1}$. The intensities of those peaks are lower compared to those of $\mathrm{MgSiO}_{3}$ due to the small cysteine amount used in the functionalization process. This process leads to an attenuation of $\mathrm{MgSiO}_{3}$ specific vibrations.

\subsection{Equilibrium Adsorption Studies. Adsorption Isotherms}

The maximum adsorption capacity of the $\mathrm{MgSiO}_{3}$-cys material was determined based on adsorption experiment data using three isotherm models: Langmuir, Freundlich, and Sips [66]. The equilibrium adsorption capacity was determined by monitoring the dependence of materials' adsorption capacity vs. initial Pd(II) concentration, illustrated in Figure 6. 


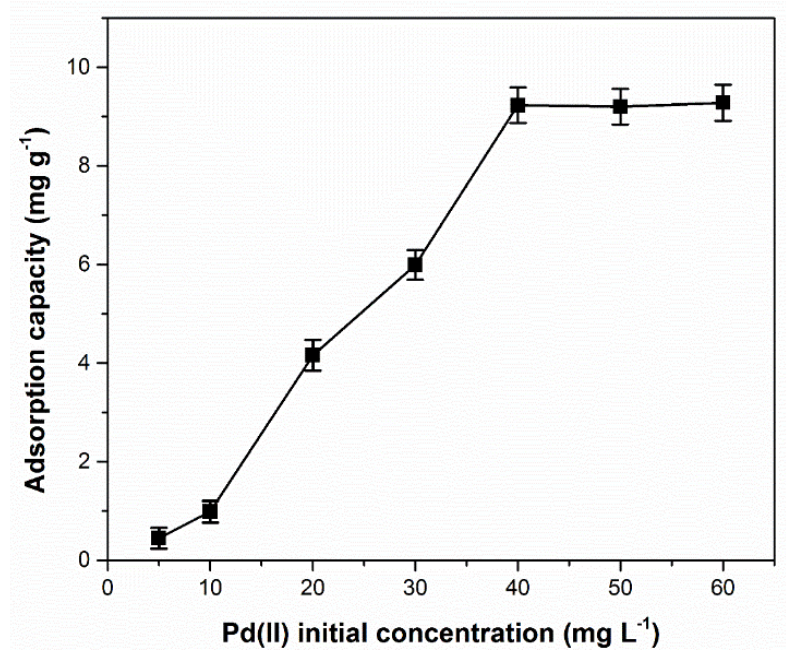

Figure 6. Influence of $\mathrm{Pd}(\mathrm{II})$ initial solution concentration on adsorption capacity of $\mathrm{MgSiO}_{3}$-cys .

Augmentation of the initial $\mathrm{Pd}(\mathrm{II})$ solution concentration led to an increase in the adsorption capacity up to an approximately constant value. The highest $\operatorname{Pd}(\mathrm{II})$ adsorption capacity $\left(q_{m}\right)$ on DL-cysteine functionalized magnesium silicate, for a steady state concentration of $40\left(\mathrm{mg} \mathrm{L}^{-1}\right)$, was $9.23\left(\mathrm{mg} \mathrm{g}^{-1}\right)$.

Figure 7 shows the equilibrium isotherms for the studied material. The parameters of the isotherm models for palladium ion adsorption on the studied functionalized material are presented in Table 1.

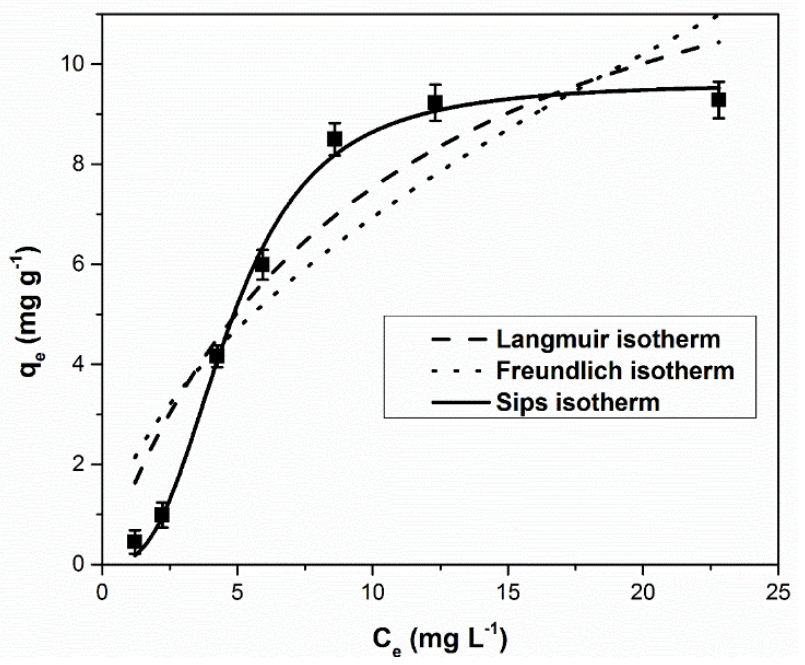

Figure 7. Equilibrium isotherms for adsorption of $\mathrm{Pd}(\mathrm{II})$ ions onto $\mathrm{MgSiO}_{3}$-cys.

The existing literature data [67] suggest that most metallic ion adsorption processes on the $\mathrm{MgSiO}_{3}$-cys material obtained by chemical modification are multilayer processes and the surface is heterogeneous. At the same time, the adsorption mechanism is controlled by chemisorption processes due to the strong chelation between metal ions and $\mathrm{OH}^{-}$groups or free electron pairs of $\mathrm{S}$ and/or $\mathrm{N}$-containing pendant groups present on the surface of the chemical functionalized material.

Using the Sips isotherm to model the obtained experimental data leads to a parameter $1 / n_{s}$ value deviated from unity, suggesting the heterogeneity of the adsorbent surface [68]. Regardless of the extractant used for functionalization, the Sips model better describes the adsorption process, reflected by the highest correlation coefficient $\left(\mathrm{R}^{2}\right)$ values. In the case of $\mathrm{Pd}(\mathrm{III})$ adsorbed on DL-cysteine functionalized magnesium silicate, the correlation coefficient of the Sips isotherm, $R^{2}=0.9953$, is higher than those obtained using the Langmuir and Freundlich adsorption isotherms. In addition, 
the calculated equilibrium adsorption capacity of the Sips model $\left(9.62 \mathrm{mg} \mathrm{g}^{-1}\right)$ was consistent with that obtained experimentally $\left(9.23 \mathrm{mg} \mathrm{g}^{-1}\right)$.

Table 1. Parameters of isotherm models for adsorption of palladium ions onto $\mathrm{MgSiO}_{3}$-cys.

\begin{tabular}{|c|c|c|c|c|c|c|c|c|c|c|}
\hline \multirow[b]{2}{*}{$\begin{array}{c}q_{m, \exp } \\
\left(\mathrm{mg} \mathrm{g}^{-1}\right)\end{array}$} & \multicolumn{3}{|c|}{ Freundlich Isotherm } & \multicolumn{3}{|c|}{ Langmuir Isotherm } & \multicolumn{4}{|c|}{ Sips Isotherm } \\
\hline & $\begin{array}{c}K_{F} \\
\left(\mathrm{mg} \mathrm{g}^{-1}\right)\end{array}$ & $1 / n$ & $\mathbf{R}^{2}$ & $\begin{array}{c}K_{L} \\
\left(\mathrm{~L} \mathrm{mg}^{-1}\right)\end{array}$ & $\begin{array}{c}q_{m} \\
\left(\mathrm{mg} \mathrm{g}^{-1}\right)\end{array}$ & $\mathbf{R}^{2}$ & $K_{S}$ & $\begin{array}{c}q_{m} \\
\left(\mathrm{mg} \mathrm{g}^{-1}\right)\end{array}$ & $1 / n_{S}$ & $\mathbf{R}^{2}$ \\
\hline 9.23 & 1.92 & 0.55 & 0.7599 & 0.10 & 14.95 & 0.8688 & 0.01 & 9.62 & 0.34 & 0.9953 \\
\hline
\end{tabular}

\subsection{Bed Height Column (BHC) Influence on the Pd(II) Breakthrough Curves}

An important parameter in the sorption process is the bed depth. Pd(II) retention in a fixed-bed column depends, among other factors, on the sorbent quantity reflected by the bed depth of the column works. Three different heights of the $\mathrm{MgSiO}_{3}$-cys sorbent filling the fixed-bed column were used in the experiments: $2.1,3.5$, and $7.0 \mathrm{~cm}$.

According to Figure 8, the column adsorption process is highlighted by establishing breakthrough curves, which represent the variation of the ratio between the residual concentration of $\mathrm{Pd}(\mathrm{II})$ and its initial concentration $\left(C_{r e z} / C_{0}\right)$, depending on the volume of effluent passed through the column, for three distinct amounts of material. Volumes of Pd(II) of $60\left(\mathrm{mg} \mathrm{L}^{-1}\right)$ concentration were varied between 1500 and $3000 \mathrm{~mL}$, depending on the amount of adsorbent material in the column.

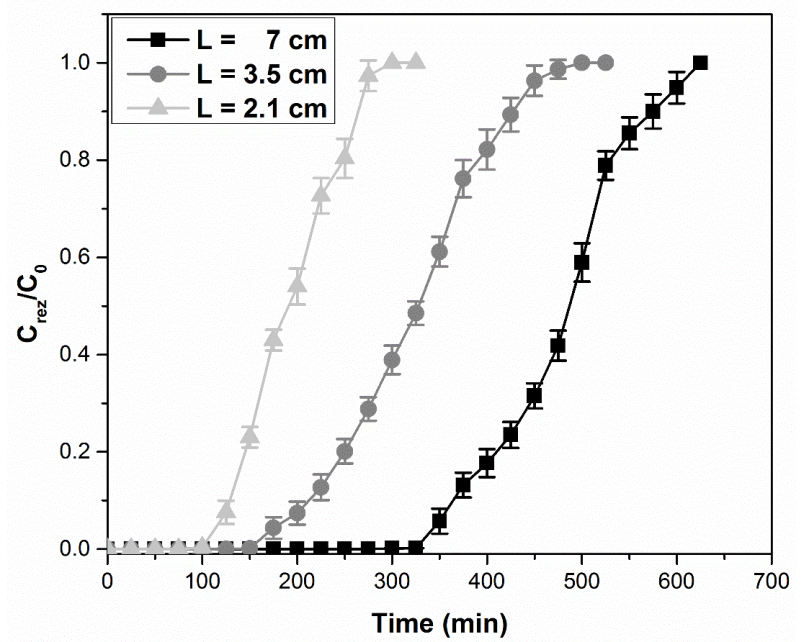

Figure 8. Breakthrough curves for $\mathrm{Pd}(\mathrm{II})$ adsorption on a $\mathrm{MgSiO}_{3}$-cys fixed-bed column at three fixed-bed bed height columns (BHCs) $\left(\mathrm{T}=298 \mathrm{~K}, \mathrm{~L}=2.1-7.0 \mathrm{~cm}, \mathrm{Ci}=60 \mathrm{mg} \mathrm{L}^{-1} \mathrm{Pd}(\mathrm{II})\right.$, and $\left.\mathrm{Q}=7 \mathrm{~mL} \mathrm{~min}{ }^{-1}\right)$.

The mass transfer area is the active surface of the bed of adsorbent material where the adsorption of $\mathrm{Pd}(\mathrm{II})$ ions takes place [65]. The first part of the column adsorption process takes place rapidly, through the adsorption of $\mathrm{Pd}(\mathrm{II})$ on the surface of the material, called the primary adsorption zone. This is why, at the beginning, the collected samples do not contain $\mathrm{Pd}(\mathrm{II})$ ions. The second part of the adsorption process is slower and is characterized by the adsorption of $\mathrm{Pd}(\mathrm{II})$ ions on the adsorbent material, achieving mass transfer. The adsorption process is complete, the concentration of Pd(II) ions varies from 60 to $0\left(\mathrm{mg} \mathrm{L}^{-1}\right)$, and the saturation of the material is total.

For the three different bed depths used, as the bed depth increases (from 2.1 at $7 \mathrm{~cm}$ ), the breakthrough point increases (from 100 to $325 \mathrm{~min}$ ). A rational explanation of this behavior is that with increasing column sorbent height a greater number of binding sites become available and the quantity of the Pd(II) removed increases accordingly [69].

A higher $\mathrm{BHC}$ leads to a longer contact time between the waste solution and the $\mathrm{MgSiO}_{3}$-cys sorbent (from about $1 \mathrm{~min}$ to $3 \mathrm{~min}$ ), having a positive influence on $\mathrm{Pd}(\mathrm{II})$ adsorption. 
Figure 8 shows an alteration of the steep concave shape to flat concave shape curves as BHC increases, which leads to an enlargement of the mass transfer area [70-72]. However, too high a layer of adsorbent material in the column is not recommended as it increases the flow resistance [73].

\subsection{Modeling for Adsorption Behaviors of $\mathrm{Pd}(\mathrm{II})$ on $\mathrm{MgSiO}_{3}-\mathrm{Cys}$}

Various practical parameters such as sorbent capacity, contact time between adsorbent and adsorbed, column operating life span, regeneration time, and prediction of the time necessarily have a significant influence upon the operation of the column. Knowing these parameters is important to model the adsorption process in a fixed-bed column.

The four models tested (Bohart-Adams, Yoon-Nelson, Thomas, and Clark) provide detailed conclusions about the process mechanism. The adsorption column is subjected to axial dispersion, external film strength, and intraparticle diffusion resistance [74].

The Bohart-Adams model is used for one-component systems and provides information on the saturation concentration of the material. This model characterizes the beginning of the column penetration, gives information about the adsorbent material used, and shows the maximum concentration at which the column is instantly broken through [60]. The Yoon-Nelson model is used to model a one-component system and provides information about the time by which half of the column is broken through. It is a purely theoretical model which does not focus on the properties of the adsorbent, the type of adsorbent, or the physical characteristics of the fixed bed [74]. The Thomas model provides information on the maximum solid phase concentration of the adsorbent and on the rate constant [62], while the Clark model describes, very well, the dynamic adsorption process [74].

\subsubsection{Bohart-Adams Model}

Figure 9 illustrates the influence of sorbent dose $(10,5$, and $3 \mathrm{~g})$ corresponding to the three previously mentioned BHCs $(7,3.5$, and $2.1 \mathrm{~cm})$ on the $\ln \left(C_{t} / C_{0}\right)$ vs. time curves. The graphic shows a direct influence of the sorbent amount upon maximum adsorption capacity, $N_{0}$, and the kinetic constant, $k_{B A}$, which indicates that, kinetically, the process is controlled by the mass transfer in the first part of the breakthrough process. The calculated regression coefficients have relatively low values (between 0.9717 and 0.9755); therefore, one can assume that the model is not the most suitable to describe the $\mathrm{Pd}(\mathrm{II})$ adsorption mechanism on $\mathrm{MgSiO}_{3}$-cys in a dynamic regime.

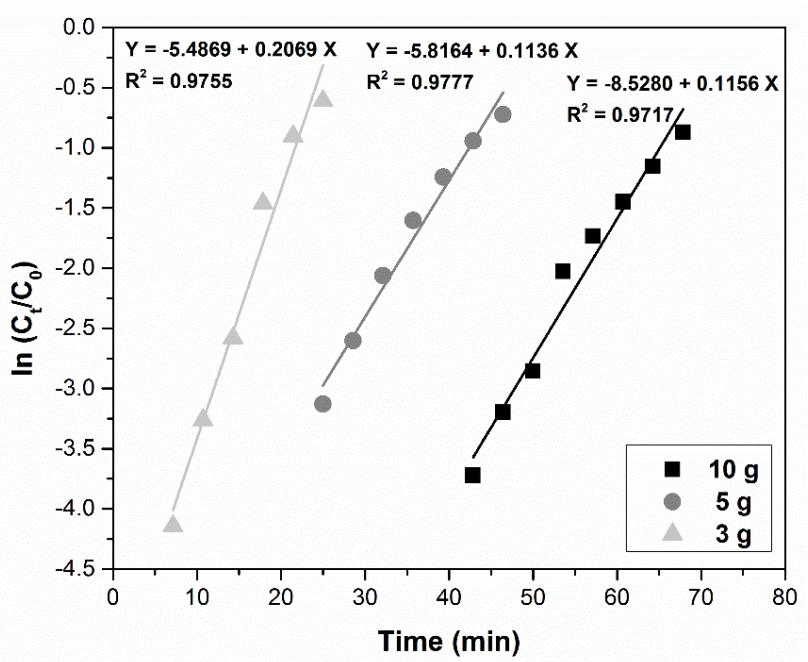

Figure 9. Bohart-Adams model for the adsorption of $\mathrm{Pd}(\mathrm{II})$ in a fixed-bed column at various $\mathrm{MgSiO}_{3}$-cys amounts. 


\subsubsection{Thomas Model}

Figure 10 shows the influence of sorbent dose $(10,5$, and $3 \mathrm{~g})$ upon the $\ln \left[\left(C_{0} / C_{t}\right)-1\right]$ vs. time curves. The figure illustrates that a higher sorbent amount leads to a decrease in the Thomas rate constant $k_{T h}$. The reason for this behavior is the adsorption driving force given by the difference between the $\mathrm{Pd}(\mathrm{II})$ concentration in the sorbent and in the solution [75-78]. The determination coefficient $\mathrm{R}^{2}$ values (between 0.9704 and 0.9961 ) indicated positive correlation, but we cannot assume that this model is best fitted for the adsorption mechanism. The adsorption capacity $q_{T h}$ and the kinetic constant are presented in Table 2.

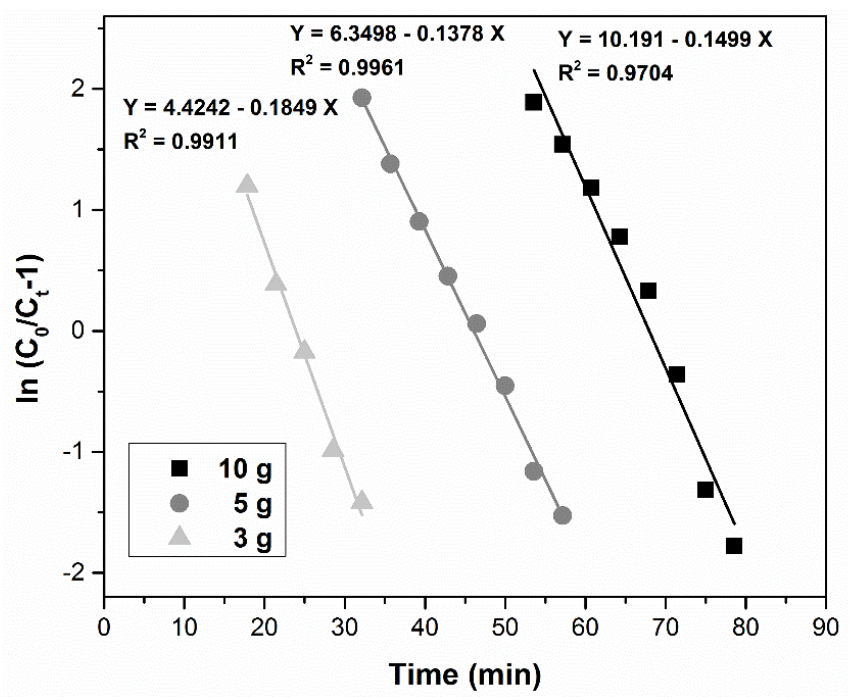

Figure 10. Thomas model for the adsorption of $\mathrm{Pd}(\mathrm{II})$ in a fixed-bed column at various $\mathrm{MgSiO}_{3}$-cys amounts.

Table 2. Pd(II) adsorption process parameters in a fixed-bed column.

\begin{tabular}{|c|c|c|c|c|}
\hline \multicolumn{5}{|c|}{ Column Adsorption Parameters Specification } \\
\hline \multirow{4}{*}{ Bohart-Adams model } & $\mathrm{MgSiO}_{3}$-cys amounts $(\mathrm{g})$ & $\begin{array}{c}k_{B A} \\
\left(\mathrm{Lmg}^{-1} \min ^{-1}\right)\end{array}$ & $\begin{array}{c}N_{0} \\
\left(\mathrm{mg} \mathrm{L}^{-1}\right)\end{array}$ & $R^{2}$ \\
\hline & 3 & $3.45 \times 10^{-3}$ & 1688.8 & 0.9755 \\
\hline & 5 & $1.89 \times 10^{-3}$ & 1960.8 & 0.9777 \\
\hline & 10 & $1.90 \times 10^{-3}$ & 1407.7 & 0.9717 \\
\hline \multirow{4}{*}{ Thomas model } & $\mathrm{MgSiO}_{3}$-cys amounts (g) & $\begin{array}{c}k_{T h} \\
\left(\mathrm{~L} \mathrm{mg}^{-1} \min ^{-1}\right)\end{array}$ & $\begin{array}{c}q_{T h} \\
\left(\mathrm{mg} \mathrm{g}^{-1}\right)\end{array}$ & $R^{2}$ \\
\hline & 3 & $2.50 \times 10^{-3}$ & 3.33 & 0.9911 \\
\hline & 5 & $2.29 \times 10^{-3}$ & 3.88 & 0.9961 \\
\hline & 10 & $2.99 \times 10^{-3}$ & 2.85 & 0.9704 \\
\hline \multirow{4}{*}{ Yoon-Nelson model } & $\mathrm{MgSiO}_{3}$-cys amounts (g) & $\begin{array}{c}k_{Y N} \\
\left(\mathrm{~min}^{-1}\right)\end{array}$ & $\underset{\tau}{\tau}$ & $R^{2}$ \\
\hline & 3 & 0.2137 & 24.40 & 0.9727 \\
\hline & 5 & 0.1376 & 46.05 & 0.9941 \\
\hline & 10 & 0.1469 & 68.30 & 0.9722 \\
\hline \multirow{4}{*}{ Clark model } & $\mathrm{MgSiO}_{3}$-cys amounts (g) & $\begin{array}{c}r \\
\left(\min ^{-1}\right)\end{array}$ & $A$ & $\mathrm{R}^{2}$ \\
\hline & 3 & 0.2156 & 9509 & 0.9936 \\
\hline & 5 & 0.1297 & 290 & 0.9973 \\
\hline & 10 & 0.1405 & 129 & 0.9881 \\
\hline
\end{tabular}




\subsubsection{Yoon-Nelson Model}

Figure 11 illustrates the relationship of $\ln \left[C_{t} /\left(C_{0}-C_{t}\right)\right]$ vs. time for the three sorbent doses. Increasing the sorbent mass leads to an increase in the breakthrough time and also in the $k_{Y N}$ constant, as it is presented in Table 2. The determination coefficient $R^{2}$ ranged between 0.9722 and 0.9941 but we cannot assume that it best describes the adsorption process.

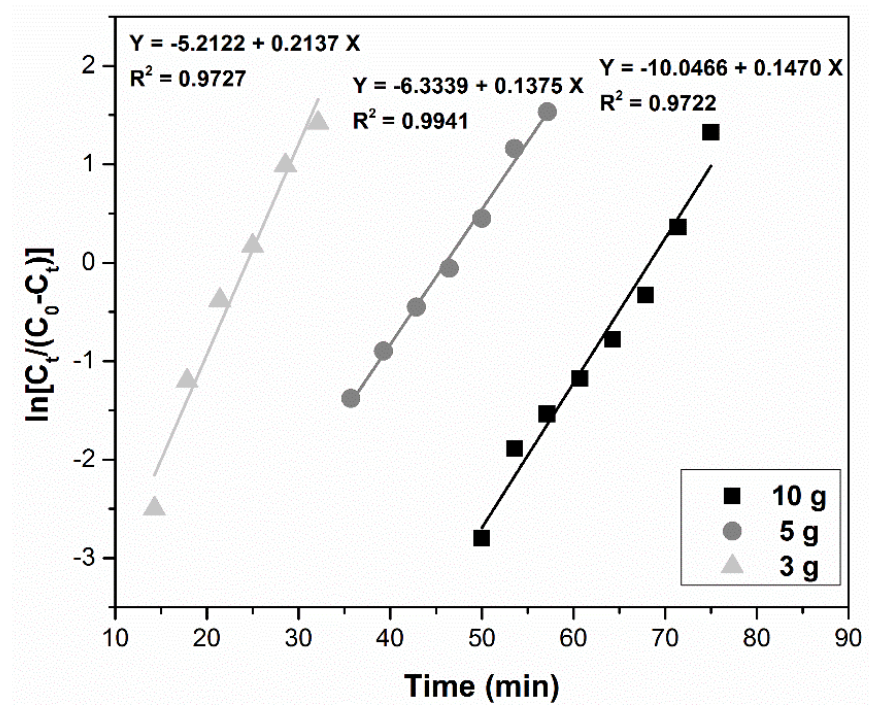

Figure 11. Yoon-Nelson model for the adsorption of $\mathrm{Pd}(\mathrm{II})$ in a fixed-bed column at various $\mathrm{MgSiO}_{3}$-cys amounts.

\subsubsection{Clark Model}

The relationship $\ln \left[\left(C_{0} / C_{t}\right)^{n-1}-1\right]$ vs. time for all adsorbent doses studied is shown in Figure 12, where $n$ is the Freundlich constant, determined experimentally in batch section. The value of this parameter was 1.81. The high values of the determination coefficient $R^{2}$ (between 0.9881 and 0.9973 ) certify that the Clark model best describes the adsorption in a fixed-bed column. The value of $r$ and $A$ parameters are presented in Table 2.

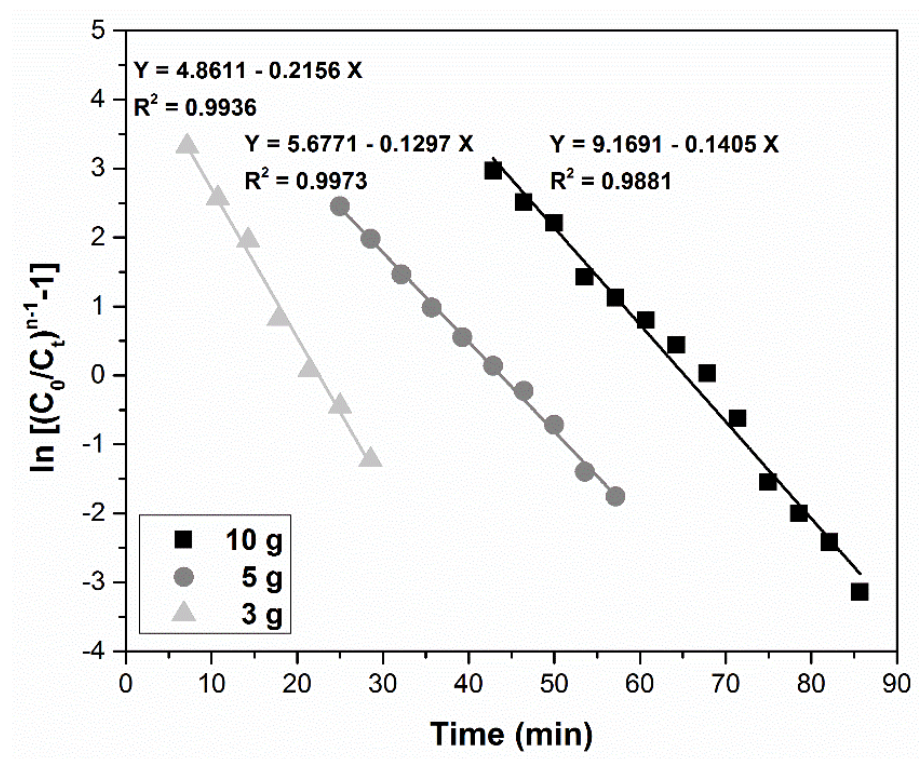

Figure 12. Clark model for the adsorption of $\mathrm{Pd}(\mathrm{II})$ in a fixed-bed column at various $\mathrm{MgSiO}_{3}$-cys amounts. 
Table 3 provides a comparison between the DL-cysteine functionalized magnesium silicate obtained in this study and other commonly used sorbents for $\mathrm{Pd}(\mathrm{II})$ removal in batch systems. The equilibrium adsorption capacity value is comparable to or even higher than those obtained in previous studies using various adsorbent materials. This behavior is based on the presence of the - $\mathrm{SH}$ and $-\mathrm{NH}_{2}$ groups in functionalized material structures, suggesting the surface adsorption of $\operatorname{Pd}(\mathrm{II})$ by free electrons or by creating hydrogen bridges.

Table 3. The equilibrium adsorption capacity of different sorbents reported in literature compared to the proposed $\mathrm{MgSiO}_{3}$-cys material.

\begin{tabular}{|c|c|c|c|}
\hline Material & Adsorption Conditions & $\begin{array}{l}\text { Adsorption Capacity, } \\
\left(\mathrm{mg} \mathrm{g}^{-1}\right)\end{array}$ & References \\
\hline Lewatit MP-500 resin & $\begin{array}{c}\text { Contact time }=2 \mathrm{~h} \\
\text { Temperature }=298 \mathrm{~K} \\
\text { Initial concentration of } \\
\mathrm{Pd}(\mathrm{II}) \text { complex }=0.1 \mathrm{M}\end{array}$ & 8.45 & [79] \\
\hline Nonylthiourea-coated $\mathrm{Fe}_{3} \mathrm{O}_{4}$ & $\begin{array}{c}\text { Contact time }=30 \mathrm{~min} \\
\text { Temperature }=295 \mathrm{~K} \\
\mathrm{pH}=2.5 \\
\text { Initial concentration of } \\
\mathrm{Pd}(\mathrm{II})=0.076\left(\mathrm{mmol} \mathrm{g}^{-1}\right)\end{array}$ & 8.10 & [80] \\
\hline $\begin{array}{l}\text { Grape stalk impregnated with } \\
\text { orthophosphoric acid }\end{array}$ & $\begin{array}{c}\text { Contact time }=4 \mathrm{~h} \\
\text { Temperature }=295 \mathrm{~K} \\
\mathrm{pH}=1.5 \\
\text { Initial concentration of } \\
\mathrm{Pd}(\mathrm{II})=60\left(\mathrm{mg} \mathrm{L}^{-1}\right)\end{array}$ & 1.4 & [81] \\
\hline $\begin{array}{l}\text { Thiocyanate retaining } \\
\text { tannin gel }\end{array}$ & $\begin{array}{l}\text { Contact time }=2 \mathrm{~h} \text {, } \\
\text { Temperature }=298 \mathrm{~K} \text {, } \\
\text { Initial concentration of } \\
\operatorname{Pd}(\mathrm{II})=0.001 \mathrm{M}\end{array}$ & 0.065 & [82] \\
\hline $\begin{array}{l}\text { Crosslinked carboxymethyl } \\
\text { chitosan hydrogels }\end{array}$ & $\begin{array}{c}\text { Contact time }=2 \mathrm{~h} \\
\text { Temperature }=295 \mathrm{~K} \\
\mathrm{pH}=4 \\
\text { Initial concentration of } \\
\mathrm{Pd}(\mathrm{II})=100 \mathrm{ppb}\end{array}$ & 2.6 & [83] \\
\hline Fungi Aspergillus sp. & $\begin{array}{l}\text { Contact time }=45 \mathrm{~min} \\
\text { Temperature }=298 \mathrm{~K} \\
\mathrm{pH}=2.5-3.5 \\
\text { Initial concentration of } \\
\mathrm{Pd}(\mathrm{II})=0.075\left(\mathrm{mg} \mathrm{L}^{-1}\right)\end{array}$ & 4.28 & {$[84]$} \\
\hline $\mathrm{MgSiO}_{3}$-cys & $\begin{array}{c}\text { Contact time }=1 \mathrm{~h} \\
\text { Temperature }=298 \mathrm{~K} \\
\mathrm{pH}=2 \\
\text { Initial concentration of } \\
\mathrm{Pd}(\mathrm{II})=40\left(\mathrm{mg} \mathrm{L}^{-1}\right)\end{array}$ & 9.23 & This paper \\
\hline
\end{tabular}

In addition, the experimental conditions in which the adsorption studies were performed, for each material, are highlighted.

\section{Conclusions}

The current paper presents a new adsorbent, $\mathrm{MgSiO}_{3}$ functionalized with DL-cysteine (cys), designed for palladium ion recovery from waste solutions.

SEM, EDX and FTIR analyses revealed morphological changes in the surface of the adsorbent material after impregnation and confirmed the functionalization of $\mathrm{MgSiO}_{3}$ with DL-cysteine. 
The modeling of the experimental data obtained in the batch system showed that the Sips isotherm best describes the adsorption process, because the correlation coefficient $\mathrm{R}^{2}$ approaches 1 and the maximum calculated adsorption capacity $\left(9.62 \mathrm{mg} \mathrm{g}^{-1}\right)$ is close to the experimentally determined value $\left(9.23 \mathrm{mg} \mathrm{g}^{-1}\right)$. The obtained adsorption capacity is better than those reported in the literature for other adsorbent materials due to the presence of the $-\mathrm{SH}$ and $-\mathrm{NH}_{2}$ groups in the structure of the functionalized material which allow the surface adsorption of $\mathrm{Pd}(\mathrm{II})$ by free electrons or by creating hydrogen bridges.

Palladium ion adsorption studies in a dynamic regime using a fixed-bed column are influenced by the adsorbent bed height (the output flow rate decreases as the fixed-bed height increases). The adsorption process is characterized by the Clark model for all the $\mathrm{MgSiO}_{3}$-cys material bed heights studied.

Author Contributions: Conceptualization, C.V., A.N., M.M., M.C. and V.M.; methodology, A.N., M.M. and G.M.; software, V.M. and G.M.; validation, C.V., A.N., P.N. and N.D.; formal analysis, A.N., N.D. and G.M.; investigation, C.V., A.N., M.M., M.C. and V.M.; resources, A.N. and P.N.; writing-original draft preparation, A.N. and M.C.; writing-review and editing, A.N. and G.M.; visualization, A.N., N.D. and P.N.; supervision, C.V. and A.N.; project administration, C.V. and A.N.; funding acquisition, C.V. and P.N. All authors have read and agreed to the published version of the manuscript.

Funding: This work was supported by a grant of the Romanian Ministry of Research and Innovation, CCCDI-UEFISCDI, project number PN-III-P1-1.2-PCCDI-2017-0391/CIA_CLIM-Smart buildings adaptable to the climate change effects, within PNCDI III.

Conflicts of Interest: The authors declare no conflict of interest.

\section{References}

1. Bailar, J.C.; Emeleus, H.J.; Nyholm, S.R.; Trotman-Dickeson, A.F. Comprehensive Inorganic Chemistry; Pergamon: Oxford, UK, 1982.

2. Kumar, A.S.K.; Sharma, S.; Reddy, R.S.; Barathi, M.; Rajesh, N. Comprehending the interaction between chitosan and ionic liquid for the adsorption of palladium. Int. J. Biol. Macromol. 2015, 72, 633-639. [CrossRef] [PubMed]

3. Rao, C.R.M.; Reddi, G.S. Platinum group metals (PGM); occurrence, use and recent trends in their determination. Trend Anal. Chem. 2000, 19, 565-586. [CrossRef]

4. Wataha, J.C.; Hanks, C.T. Biological effects of palladium and risk of using palladium in dental casting alloys. J. Oral. Rehabil. 1996, 23, 309-320. [CrossRef]

5. Wolowicz, A.; Hubicki, Z. Comparison of strongly basic anion exchange resins applicability for the removal of palladium(II) ions from acidic solutions. Chem. Eng. J. 2011, 171, 206-215. [CrossRef]

6. Butler, J. Platinum Interim Review 2010; Johnson Matthey: Royston, UK, 2010.

7. Farrauto, R.J.; Heck, R.M. Catalytic converters: State of the art and perspectives. Catal. Today 1999, 51, 351-360. [CrossRef]

8. Polshettiwar, V.; Len, C.; Fihri, A. Silica-supported palladium: Sustainable catalysts for cross-coupling reactions. Coord. Chem. Rev. 2009, 253, 2599-2626. [CrossRef]

9. Sharma, R.K.; Pandey, A.; Gulati, S.; Adholeya, A. An optimized procedure for preconcentration, determination and on-line recovery of palladium using highly selective di-phenyl-di-ketone-mono-thio-semi-carbazone modified silica gel. J. Hazard. Mater. 2012, 209-210, 285-292. [CrossRef]

10. Bernardis, F.L.; Grant, R.A.; Sherrington, D.C. A review of methods of separation of the platinum-group metals through their chloro-complexes. React. Funct. Polym. 2005, 65, 205-217. [CrossRef]

11. Cui, J.; Zhang, L. Metallurgical recovery of metals from electronic waste: A review. J. Hazard. Mater. 2008, 158, 228-256. [CrossRef]

12. Gaita, R.; Al-Bazi, S.J. An ion-exchange method for selective separation of palladium, platinum and rhodium from solutions obtained by leaching automotive catalytic converters. Talanta 1995, 2, 249-255. [CrossRef]

13. Kononova, O.N.; Leyman, T.A.; Melnikov, A.M.; Kashirin, D.M.; Tselukovskaya, M.M. Ion exchange recovery of platinum from chloride solutions. Hydrometallurgy 2010, 100, 161-167. [CrossRef]

14. Park, Y.J.; Fray, D.J. Recovery of high purity precious metals from printed circuit boards. J. Hazard. Mater. 2009, 164, 1152-1158. [CrossRef] [PubMed] 
15. Rao, S.R. Resource Recovery and Recycling from Metallurgical Wastes; Elsevier: Amsterdam, The Netherlands, 2006.

16. Durosaro, O.; el-Azhary, R.A. A 10-year Retrospective Study on Palladium Sensitivity. Dermatitis 2009, 20, 208-213. [CrossRef] [PubMed]

17. Shultz, M.D.; Lassig, J.P.; Gooch, M.G.; Evans, B.R.; Woodward, J. Palladium a new inhibitor of cellulase activities. Biochem. Biophys. Res. Commun. 1995, 209, 1046-1052. [CrossRef] [PubMed]

18. Kielhorn, J.; Melber, C.; Keller, D.; Mangelsdorf, I. Palladium-A review of exposure and effects to human health. Int. J. Hyg. Environ. Health 2002, 205, 417-432. [CrossRef] [PubMed]

19. Borges, D.L.G.; Veiga, M.A.M.S.D.; Frescura, V.L.A.; Welz, B.; Curtius, A.J. Cloudpoint extraction for the determination of $\mathrm{Cd}, \mathrm{Pb}$ and $\mathrm{Pd}$ in blood by electrothermal atomic absorption spectrometry, using $\mathrm{Ir}$ or $\mathrm{Ru}$ as permanent modifiers. J. Anal. At. Spectrom. 2003, 18, 501-507. [CrossRef]

20. Ghaedi, M.; Shokrollahi, A.; Niknam, K.; Niknam, E.; Najibi, A.; Soylak, M. Cloud point extraction and flame atomic absorption spectrometric determination of cadmium(II), lead(II), palladium(II) and silver(I) in environmental samples. J. Hazard. Mater. 2009, 168, 1022-1027. [CrossRef]

21. Komarek, J.; Krasensky, P.; Balcar, J.; Rehulka, P. Determination of palladium and platinum by electrothermal atomic absorption spectroscopy after deposition on a graphite furnace. Spectrochim. Acta B 1999, 54, 739-743. [CrossRef]

22. Lee, J.Y.; Raju, B.; Kumar, B.N.; Kumar, J.R.; Park, H.K.; Reddy, B.R. Solvent extraction separation and recovery of palladium and platinum from chloride leach liquors of spent automobile catalyst. Sep. Purif. Technol. 2010, 73, 213-218. [CrossRef]

23. Pan, L.; Zhang, Z. Solvent extraction and separation of palladium (II) and platinum (IV) from hydrochloric acid medium with dibutyl sulfoxide. Miner. Eng. 2009, 22, 1271-1276. [CrossRef]

24. Priya, B.K.; Subrahmanayam, P.; Suvardhan, K.; Kumar, K.S.; Rekha, D.; Rao, A.V.; Rao, G.C.; Chiranjeevi, P. Cloud point extraction of palladium in water samples and alloy mixtures using new synthesized reagent with flame atomic absorption spectrometry. J. Hazard. Mater. 2007, 144, 152-158. [CrossRef] [PubMed]

25. Soylak, M.; Tuzen, M. Coprecipitation of gold(III), palladium(II) and lead(II) for their flame atomic absorption spectrometric determinations. J. Hazard. Mater. 2008, 152, 656-661. [CrossRef] [PubMed]

26. Bulut, V.N.; Tufekci, M.; Duran, C.; Soylak, M.; Kantekin, H. Selective Solid Phase Extraction for Separation and Preconcentration of Palladium from Gold Ore and Anode Slime after Complexation with a $\mathrm{N}_{4} \mathrm{O}_{2}$ Mixed Donor Ligand Derivative. Clean 2010, 38, 678-683. [CrossRef]

27. Elci, L.; Soylak, M.; Buyuksekerci, E.B. Separation of gold, palladium and platinum from metallurgical samples using an Amberlite XAD-7 resin column prior to their atomic absorption spectrometric determinations. Anal. Sci. 2003, 19, 1621-1624. [CrossRef] [PubMed]

28. Sharma, R.K.; Mittal, S.; Koel, M. Analysis of trace amounts of metal ions using silica-based chelating resins: A green analytical method. Crit. Rev. Anal. Chem. 2003, 33, 183-197. [CrossRef]

29. Soylak, M.; Elci, L. A sorbent extraction procedure for the preconcentration of gold, silver and palladium on an activated carbon column. Anal. Lett. 2000, 33, 513-525. [CrossRef]

30. Ciopec, M.; Davidescu, C.M.; Negrea, A.; Muntean, C.; Popa, A.; Negrea, P.; Lupa, L. Equilibrium and Kinetic Studies of the Adsorption of Cr(III) ions onto Amberlite XAD8 impregnated with Di (2-ethylhexyl) phosphoric acid (DEHPA). Adsorp. Sci. Technol. 2011, 29, 989-1005. [CrossRef]

31. Davidescu, C.M.; Ciopec, M.; Negrea, A.; Popa, A.; Lupa, L.; Dragan, E.S.; Ardelean, R.; Ilia, G. Synthesis, characterization and $\mathrm{Ni}(\mathrm{II})$ Ion separation properties of poly(styrene-co-divinylbenzene)-supported aminophosphonic acids. Polym. Bull. 2013, 70, 277-291. [CrossRef]

32. Negrea, A.; Ciopec, M.; Lavinia, L.; Davidescu, C.M.; Popa, A.; Ilia, G.; Negrea, P. Removal of As(V) by Fe(III) loaded XAD7 impregnated resin containing di(2-ethylhexyl) phosphoric acid DEHPA): Equilibrium, Kinetic, and Thermodynamic modeling studies. J. Chem. Eng. Data 2011, 565, 3830-3838. [CrossRef]

33. Kovacheva, P.; Djingova, R. Ion-exchange method for separation and concentration of platinum and palladium for analysis of environmental samples by inductively coupled plasma atomic emission spectrometry. Anal. Chim. Acta 2002, 464, 7-13. [CrossRef]

34. Enzweiler, J.; Potts, P.J. The separation of platinum, palladium and gold from silicate rocks by the anion exchange separation of chloro complexes after a sodium peroxide fusion: An investigation of low recoveries. Talanta 1995, 42, 1411-1418. [CrossRef]

35. Els, E.R.; Lorenzen, L.; Aldrich, C. The recovery of palladium with the use of ion exchange resins. Miner. Eng. 1997, 10, 1177-1181. [CrossRef] 
36. Kim, K.R.; Lee, M.S.; Ahn, D.H.; Yim, S.P.; Chung, H. Preparation of functional anion exchange resin and its selective adsorption of palladium in nitric acid medium. J. Ind. Eng. Chem. 2002, 8, 472-476.

37. Lee, S.H.; Chung, H. Ion exchange characteristics of palladium and rhodium from a simulated radioactive liquid waste. J. Nucl. Sci. Technol. 2000, 37, 281-287. [CrossRef]

38. Lee, S.H.; Chung, H. Ion exchange characteristics of palladium and ruthenium from a simulated radioactive liquid waste. Sep. Sci. Technol. 2003, 38, 3459-3472. [CrossRef]

39. Lee, S.H.; Kim, K.R.; Jung, C.H.; Chung, H. Ion exchange characteristics of palladium from nitric acid solution by anion exchangers. Korean J. Chem. Eng. 1999, 16, 571-575. [CrossRef]

40. Hubicki, Z.; Leszczynska, M. Sorption of palladium(II) chloride complexes on weakly, intermediate and strongly basic anion exchangers. Desalination 2005, 175, 227-236. [CrossRef]

41. Hubicki, Z.; Leszczynska, M. Studies of sorption of Pd(II) micro quantities on strongly basic polyacrylate anion exchangers. Desalination 2005, 175, 289-295. [CrossRef]

42. Negrea, A.; Gabor, A.; Davidescu, C.M.; Ciopec, M.; Muntean, C.; Negrea, P.; Duteanu, N.; Barbulescu, A. Rare Earth Elements Removal from Water Using Natural Polymers. Sci. Rep. 2018, 8, 316. [CrossRef]

43. Gabor, A.; Davidescu, C.M.; Negrea, A.; Ciopec, M.; Lupa, L. Behaviour of silica and florisil as solid supports in the removal process of As(V) from aqueous solutions. J. Anal. Methods Chem. 2015, 2015, 562780. [CrossRef]

44. Gabor, A.; Davidescu, C.M.; Popa, A.; Negrea, A.; Ciopec, M.; Motoc, M.; Lupa, L.; Negrea, P. Equilibrium studies for crown ether impregnated solid support used in the removal process of $\mathrm{Nd}(\mathrm{III}), \mathrm{La}(\mathrm{III}), \mathrm{Sr}(\mathrm{II}), \mathrm{Tl}(\mathrm{I})$, Eu(III). Rev. Chim. 2016, 67, 580-583.

45. Gabor, A.; Davidescu, C.M.; Negrea, A.; Ciopec, M.; Muntean, C.; Negrea, P.; Ianasi, C.; Butnariu, M. Magnesium silicate doped with environmentally friendly extractants used for rare earth elements adsorption. Desalin. Water. Treat. 2017, 63, 124-134.

46. Negrea, A.; Popa, A.; Ciopec, M.; Lupa, L.; Negrea, P.; Davidescu, C.M.; Motoc, M.; Minzatu, V. Phosphonium grafted styrene- divinylbenzene resins impregnated with iron(III) and crown ethers for arsenic removal. Pure Appl. Chem. 2014, 86, 1729-1740. [CrossRef]

47. Ciopec, M.; Davidescu, C.M.; Negrea, A.; Grozav, I.; Lupa, L.; Muntean, C.; Negrea, P.; Popa, A. Statistical optimization of chromium ions adsorption on DEHPA-impregnated Amberlite XAD7. Environ. Eng. Manag. J. 2012, 11, 525-531. [CrossRef]

48. Benamor, M.; Bouariche, Z.; Belaid, T.; Draa, M.T. Kinetic studies on cadmium ions by Amberlite XAD7 impregnated resin containing di(2-ethylhexyl) phosphoric acid as extractant. Sep. Purif. Technol. 2008, 59, 74-84. [CrossRef]

49. Cortina, J.L.; Warshawsky, A. Developments in Solid-Liquid Extraction by Solvent-Impregnated Resins. In Ion Exchange and Solvent Extraction; Marinsky, J.A., Marcus, Y., Eds.; Marcel Dekker Inc.: New York, NY, USA, 1997; pp. 195-293.

50. Davidescu, C.M.; Ciopec, M.; Negrea, A.; Popa, A.; Lupa, L.; Negrea, P.; Muntean, C.; Motoc, M. Use of di-(2-ethylhexyl)phosphoric acid (DEHPA) impregnated XAD7 copolymer resin for the removal of chromium (III) from water. Rev. Chim. 2011, 62, 712-717.

51. Juang, R.S. Preparation, properties and sorption behaviour of impregnated resin containing acidic organo-phosphorus extractants. Proc. Natl. Sci. Counc. ROC(A) 1999, 23, 353-364.

52. Mendoza, R.N.; Medina, I.S.; Vera, A.; Rodriguez, M.A. Study of the sorption of Cr(III) with XAD-2 resin impregnated with di-(2,4,4-trimethylpentyl) phosphinic acid (Cyanex 272). Solvent Extr. Ion Exch. 2000, 18, 319-343. [CrossRef]

53. Muraviev, D.; Ghantous, L.; Valiente, M. Stabilization of solvent impregnated resin capacities by different techniques. React. Funct. Polym. 1998, 38, 259-268. [CrossRef]

54. Disbudak, A.; Bektas, S.; Patir, S.; Genc, O.; Denizli, A. Cysteine-metal affinity chromatography: Determination of heavy metal adsorption properties. Sep. Purif. Technol. 2002, 26, 273-281. [CrossRef]

55. Hisada, M.; Kawase, Y. Recovery of rare-earth metal neodymium from aqueous solutions by poly-g-glutamic acid and its sodium salt as biosorbents: Effects of solution $\mathrm{pH}$ on neodymium recovery mechanisms. J. Rare Earth 2018, 36, 528-536. [CrossRef]

56. Langmuir, I. The adsorption of gases on plane surfaces of glass, mica and platinum. J. Am. Chem. Soc. 1918, 40, 1361-1403. [CrossRef]

57. Kucuker, M.A.; Wieczorek, N.; Kuchta, K.; Copty, N.K. Biosorption of neodymium on Chlorella vulgaris in aqueous solution obtained from hard disk drive magnets. PLoS ONE 2017, 12, e0175255. [CrossRef] 
58. Freundlich, H.M.F. Over the adsorption in solution. J. Phys. Chem. 1906, 57, 385-470.

59. Sips, R. On the Structure of a Catalyst Surface. J. Chem. Phys. 1948, 16, 490-495. [CrossRef]

60. Bohart, G.S.; Adams, E.Q. Some aspects of the behaviour of charcoal with respect to chlorine, Behaviour of charcoal toward chlorine. Am. Chem. Soc. 1920, 42, 523-544. [CrossRef]

61. Chu, K.H. Breakthrough curve analysis by simplistic models of fixed bed adsorption: In defense of the century-old Bohart-Adams model. Chem. Eng. J. 2020, 380, 122513. [CrossRef]

62. Thomas, H.C. Heterogeneous ion exchange in a flowing system. J. Am. Chem. Soc. 1944, 66, 1664-1666. [CrossRef]

63. Vilvanathan, S.; Shanthakumar, S. Removal from Aqueous Solution Using Native and Biochar Form of Tectona grandis. Environ. Prog. Sustain. Energy 2017, 36, 1030-1038. [CrossRef]

64. Dlugosz, O.; Banach, M. Sorption of $\mathrm{Ag}^{+}$and $\mathrm{Cu}^{2+}$ by Vermiculite in a Fixed-Bed Column: Design, Process Optimization and Dynamics Investigations. Appl. Sci. 2018, 8, 2221. [CrossRef]

65. Madan, S.S.; De, B.S.; Wasewar, K.L. Adsorption performance of packed bed column for benzylformic acid removal using $\mathrm{CaO}_{2}$ nanoparticles. Chem. Data Collect. 2019, 23, 100267. [CrossRef]

66. Sert, S.; Kutahyali, C.; Inan, S.; Talip, Z.; Cetinkaya, B.; Eral, M. Biosorption of lanthanum and cerium from aqueous solutions by Platanus orientalis leaf powder. Hydrometallurgy 2008, 90, 13-18. [CrossRef]

67. Zhang, P.; Wang, Y.; Zhang, D.; Bai, H.; Tarasov, V.V. Calixarene-functionalized Graphene Oxide Composites for Adsorption of Neodymium Ions from aqueous phase. RSC Adv. 2016, 6, 30384-30394. [CrossRef]

68. Dzieniszewska, A.; Kyziol-Komosinska, J.; Pajak, M. Adsorption and bonding strength of chromium species by ferrihydrite from acidic aqueous solutions. PeerJ 2020, 8, e9324. [CrossRef] [PubMed]

69. Mohammed, N.; Grishkewich, N.; Waeijen, H.A.; Berry, R.M.; Tam, K.C. Continuous flow adsorption of methylene blue by cellulose nanocrystalalginate hydrogel beads in fixed bed columns. Carbohydr. Polym. 2016, 136, 1194-1202. [CrossRef] [PubMed]

70. Chowdhury, Z.Z.; Zain, S.M.; Rashid, A.K.; Rafique, R.F.; Khalid, K. Breakthrough curve analysis for column dynamics sorption of Mn(II) ions from wastewater by using Mangostana garcinia peel-based granular-activated carbon. J. Chem. 2013, 2013, 959761. [CrossRef]

71. Hasanzadeh, M.; Ansari, R.; Ostovar, F. Synthesis and application of $\mathrm{CeO}_{2} /$ sawdust nanocomposite for removal of As(III) ions from aqueous solutions using a fixed bed column system. Glob. NEST J. 2016, 19, 7-16.

72. Shafeeyan, M.S.; Daud, W.M.A.W.; Shamiri, A. A review of mathematical modeling of fixed-bed columns for carbon dioxide adsorption. Chem. Eng. Res. Des. 2014, 92, 961-988. [CrossRef]

73. Netpradit, S.; Thiravetyan, P.; Towprayoon, S. Evaluation of metal hydroxide sludge for reactive dye adsorption in a fixed-bed column system. Water Res. 2004, 38, 71-78. [CrossRef]

74. Patel, H. Fixed-bed column adsorption study: A comprehensive review. Appl. Water Sci. 2019, 9, 45. [CrossRef]

75. Soto, M.L.; Moure, A.; Dominguez, H.; Parajo, J.C. Batch and fixed bed column studies on phenolic adsorption from wine vinasses by polymeric resins. J. Food Eng. 2017, 209, 52-60. [CrossRef]

76. Han, R.P.; Wang, Y.; Zou, W.H.; Wang, Y.F.; Shi, J. Comparison of linear and nonlinear analysis in estimating the Thomas model parameters for methylene blue adsorption onto natural zeolite in fixed-bed column. J. Hazard. Mater. 2007, 145, 331-335. [CrossRef] [PubMed]

77. Han, R.P.; Zhang, J.H.; Zou, W.H.; Xiao, H.J.; Shi, J.; Liu, H.M. Biosorption of copper(II) and lead(II) from aqueous solution by chaff in a fixed-bed column. J. Hazard. Mater. 2006, 133, 262-268. [CrossRef]

78. Mondal, S.; Aikat, K.; Halder, G. Ranitidine hydrochloride sorption onto superheated steam activated biochar derived from mung bean husk in fixed bed column. Biochem. Pharmacol. 2016, 4, 488-497. [CrossRef]

79. Wolowicz, A.; Hubicki, Z. Palladium(II) complexes adsorption from the chloride solutions with macrocomponent addition using strongly basic anion exchange resins, type 1. Hydrometallurgy 2009, 98, 206-212. [CrossRef]

80. Uheida, A.; Iglesias, M.; Fontas, C.; Zhang, Y.; Muhammed, M. Adsorption Behaviour of Platinum Group Metals (Pd, Pt, $\mathrm{Rh}$ ) on Nonylthiourea-Coated $\mathrm{Fe}_{3} \mathrm{O}_{4}$ Nanoparticles. Sep. Sci. Technol. 2006, 41, 909-923. [CrossRef]

81. Mavhungu, A.; Mbaya, R.K.K.; Moropeng, M.L. Recovery of Platinum and Palladium Ions from Aqueous Solution Using Grape Stalk Waste. Int. J. Chem. Eng. Appl. 2013, 4, 354-358. [CrossRef]

82. Morisada, S.; Kim, Y.H.; Yakuwa, S.; Ogata, T.; Nakano, Y. Improved adsorption and separation of palladium(II) and platinum(IV) in strong hydrochloric acid solutions using thiocyanate-retaining tannin gel. J. Appl. Polym. Sci. 2012, 126, E478-E483. [CrossRef] 
83. Wasikiewicz, J.M.; Mitomo, H.; Seko, N.; Tamada, M.; Yoshii, F. Platinum and Palladium Ions Adsorption at the Trace Amounts by Radiation Crosslinked Carboxymethylchitin and Carboxymethylchitosan Hydrogels. J. Appl. Polym. Sci. 2007, 104, 4015-4023. [CrossRef]

84. Godlewska-Zylkiewicz, B.; Sawicka, S.; Karpinska, J. Removal of Platinum and Palladium from Wastewater by Means of Biosorption on Fungi Aspergillus sp. and Yeast Saccharomyces sp. Water 2019, 11, 1522. [CrossRef]

Publisher's Note: MDPI stays neutral with regard to jurisdictional claims in published maps and institutional affiliations.

(C) 2020 by the authors. Licensee MDPI, Basel, Switzerland. This article is an open access article distributed under the terms and conditions of the Creative Commons Attribution (CC BY) license (http://creativecommons.org/licenses/by/4.0/). 